Article

\title{
Study on the in-depth reasons and mechanisms of globalization and anti-globalization
}

\author{
Ma yisha
}

1 Affiliation 1;253976439@qq.com

2 Affiliation 2; ma.yisha@phd.must.edu.my

\begin{abstract}
Since the financial crisis in 2008, the U.S. economy has weakened, and the world economy has slowly developed. As the world's leading country, the United States has used many methods to restore the economy. But it does work efficiently. However, there are many issues in developed countries such as domestic social, economic, immigration in the United States/United Kingdom; those are not optimistic. Developed countries have entered a dilemma. The neoliberalism financial system has been unable to move forward. Populists have pointed out that those problems have been causing by globalization. Under the leadership of the Brexit Referendum, President Trump has caused a wave of anti-globalization. Under a series of systems such as the China-US trade war and the US-Mexico border wall repairs, the anti-globalization trend is getting stronger. This article mainly analyzes the in-depth reasons and mechanism research of globalization and anti-globalization alternately-the data obtained from an international method performance study. The results show that anti-globalization is temporary, along with globalization. There are three main factors affecting globalization: the situation of the dominant country, natural disasters, and wars. After so much literature review, I believe that the United States' globalization is gradually weakening, and globalization may return to regionalization under the United States' opposition.
\end{abstract}

Keywords: anti-globalization; economic globalization; US-dominated globalization

\section{Introduction}

The term globalization is a concept and a process of phenomena in the development of human society. Globalization has made markets more responsive and flexible. There are many definitions of globalization. Globalization refers to the continuous increase of global connections, human life on a worldwide scale, and the rise of global consciousness. Countries are interdependent in politics, economy, and trade. Globalization can also interpret as the compression of the world and the international as a whole. Economic globalization is the core of globalization, which is the objective requirement of developing productive social forces and the inevitable result of scientific and technological progress. It provides a strong impetus for world economic growth, promotes the flow of goods and capital, advances in science and technology and civilization, and the exchanges between people of all countries. Globalization has encouraged the flow of goods and money, the advancement of science and technology and culture, the sales of people of all nations, the improvement of people's livelihood, and the promotion of unprecedented prosperity in human society. 
Global problems, also known as world problems, refer to those problems that determine the common destiny and can only be solved by joint efforts. These are problems related to natural, social, and spiritual, such as the ecological balance, environmental pollution, food security, resource shortage, population, refugees, drug crimes, war and peace, north-south relations, nationalism, the global climate, international terrorism, space exploration and ocean development and so on. Above the influence of the problems and permeate each other with the following characteristics; First, global, these problems are not isolated issues in some local areas of some countries, but difficulties universal in the world. The second is totality, which means that these problems involve all sectors and regions of human life. Third, they are serious; that is, they are challenging and threatening in nature and influence, and they have a direct bearing on the survival and development of all humankind.

The mean of anti-globalization is the conflict brought about by the difference of market occupation and capital flow mode and a degree in the economic globalization stage, which forms the subjective intention to restrict or even close the international flow of production factors. It gradually degenerates from the global political-economic relationship to the regional relationship or even the bilateral relationship.

Globalization" and "anti-globalization are coexisting. Anti-globalization" is indeed exerting significant and influence on the international community in various forms. To deal with "globalization" or "diverse globalization", we should not merely support or resist but should treat it with an attitude of objective rationality. The purpose of the anti-globalization movement is not to block or change globalization but to strive for its benefits. Moreover, "globalization" is an inevitable choice in history, which is an irreversible historical trend. Even the anti-globalists do not deny this point entirely. The "anti-globalization" movement has become an integral part of the "globalization" process to some extent.

The outbreak of COVID-19(Farmer Kevin C. 2021). has reversed the forces of economic globalization and impacted all aspects of global governance. The root cause of the failure of global government is that the global governance system established after World War II has not changed with the stages of economic globalization. The initiator of globalization, the developed capitalist countries such as the United States and Europe, gradually set off a tide of "anti-globalization". How did globalization and anti-globalization evolve in history? What are the internal logic and fundamental reasons for its evolution? How can humanity emerge from the fog of the present and move forward on the road to the future? To clarify these problems is the theoretical premise and practical basis for us to correctly understand and analyze the current trend of "anti-globalization."

\section{Methodology}

This article adopts the method of empirical analysis to conduct qualitative research on world economic history, find historical data of global history, collect and sort them, then integrate them, and finally hand-paint them into the article. The use of historical analysis makes it easy to find the law of alternation between globalization and anti-globalization. This article also conducts quantitative research. Based on the World Bank data, a clear and intuitive chart of the percentage of GDP per capita in the United States is established, which is easy for readers to understand and analyze the US crisis in combination with history. It also allows us to understand the history of the US crisis. , As long as you actively respond. From the study of economic history, it is easy to discover the laws of events that are happening now to understand the current world phenomenon better. However, another limitation in this article is the difficulty of obtaining evidence from historical materials. I have fewer historical documents in 
China for the world and other countries, especially for economic history. It is more difficult to read English documents. The original version can only glimpse one or two from the Chinese analysis of other scholars. It is also challenging to obtain data forensics because of geographic restrictions. World bank.com did not open. I also checked the World Bank data on the third-rate website in my country, but the credibility is not high. To increase the authenticity of the data, I worked late at night. I finally entered the official website of the World Bank when no one crowded.

In this article, to find out the causes of actual problems from theoretical research, how to better discover the rules of alternation between globalization and anti-globalization, there are five historical forms of globalization in the world's global history the two alternate with each other, Interdependence. There is also the reliability and traceability of historical evidence collection and the freedom of information accessible to everyone at hand. Compared with the content of confidential documents, there is a degree of recognition, which reduces other disputes.

\section{The effects of globalization and anti-globalization}

Globalization is an irresistible trend in the development and progress, but as the twin creatures of globalization, anti-globalization has always accompanied. Up to now, human beings have experienced five waves of globalization and anti-globalization, and globalization has made tortuous progress in its "periodic movements." Under neo-liberal institutionalism, globalization has developed. There is an imbalance of free trade and national interests in western capitalist countries, which is the direct cause of the anti-globalization.

3.1 The history of globalization

- $\quad$ GGlobalization 1.0 (1500BC) Ancient Egypt dominates globalization.

- $\quad$ Globalization 2.0 (11th century AD-13th century) Roman Empire globalization

- $\quad$ Globalization 3.0 (1279-1350) Mongol Empire builds the globalization.

- $\quad$ G Globalization 4.0 (1492-1913) British-dominated globalization

- uGlobalization 5.0 (1944-now) US-dominated globalization

For the first time, ancient Egypt Egypt was in 1500 BC, during the eighteenth dynasty. At that time, there was globalization. Egypt dominated it, which is equivalent to the current United States. It has already formed a region in the eastern Mediterranean. The network of a large division of labor and long-distance trade, dominated by powerful countries, has constituted the first round of globalization. Subsequently, the Egyptian empire's decline caused the entire division of labor and trade system to collapse, and the world fell into chaos. It is the first of the globalization disappeared.

The second time, 200 years after the Roman Empire's establishment in the Roman era, was the peak of globalization. Under the Roman Empire's leadership, a regional division of labor and long-distance 
trade was carried out on a larger scale in Europe during this period. Rome is the center for business exchanges. After the Roman Empire's decline, this highly interdependent and delicate division of labor systems collapsed instantly. Finally, regressed to the manor economy, reverted to the feudal system. This process continued until the 11 th to 13 th century A.D.;

Thirdly, the first golden globalization was from the 13th to the 14th century. It is the era under the rule of Genghis Khan and his descendants. The route they built and protected opened up a new world full of possibilities. Europeans can buy silk and other rare textiles, foreign spices. All dependent countries and indirectly controlled countries had forced to set up post stations without choice. Through post information, international trade can quickly transfer, and cultural exchanges can also actively develop. Post stations have become the first established transportation between Europe and Asia in human history. Though with the demise of the Mongol Empire, globalization naturally ended.

Globalization 4.0 had formed by the United Kingdom. After two industrial revolutions, the United Kingdom became a strong empire. However, with the two world wars, Britain's national become weakened, and the United States rose and then replace him.

The U.S. economy became a world power after World War II, so he presided over the world order and established world organizations such as the World Bank, WTO, World Fund, etc. Since entering the 21 st century, especially after the outbreak of the international financial crisis in 2008, due to the slow recovery of the world economy, the world economic turmoil has caused a series of political and social problems. A series of "black swan" events include:

पThe Brexit referendum.

पTrade battle between the U.S. and China.

DUnilateralism.

口Border wall repairs.

Dlmmigration control.

3.2 Globalization the effects on the group of nations, international company, people

Globalization is the product of economic and technological development in the world today, and it has become an irreversible trend and an irresistible objective reality. It brings development opportunities to all countries, but also severe challenges and risks. However, due to the difference in initial capital, globalization's impact on each country is also different. As an active promoter of globalization, developed countries use their advantages and monopoly positions in international trade, international production and investment, and high-tech industries to gradually establish a global economic order conducive to developed countries in globalization and become The biggest recipient of globalization. With plenty of labor resources and low prices, developing countries have the natural advantage of undertaking labor-intensive industries in developed countries. Globalization can give developing countries opportunities to participate in international affairs and gradually enhance their global voice and market competitiveness. Due to the reason such as the insufficient long-term development level, the low level of technological innovation, the failure of the formed industry a complete system, and the low economic development capabilities in developing countries, they are in a significantly disadvantaged position in the 
wave of economic globalization. The national division of labor is often at a disadvantage. Developed countries dominate the lower class. Developing countries have inexperienced, limited level, weak resistance to shocks, weak market mechanisms, imperfect financial systems in economic development, and are vulnerable to economic fluctuations in developed countries, such as the Greek debt crisis(Ladi, S., \& Spyropoulou, V. 2019).

Nowadays, the world market is open broad; the industrial chain is globalized, the communication chain is globalized. Therefore plenty of products be sold, and international companies' profits are getting higher and higher. This article takes the U.S. Apple as an example to describe the global journey of a mobile phone. First, design and research in the United States, and purchase equipment and materials in the United States, Europe, and other countries. The procurement of mobile phone materials also comes from many countries in the world. Finally, the mobile phone assembled in China. Among them, its suppliers are mainly from Asia, such as South Korea, Japan offers the display, Japan's Sony provides the camera, and Japan also provides the storage. China Taiwan provides A8 chips, and China provides housing.
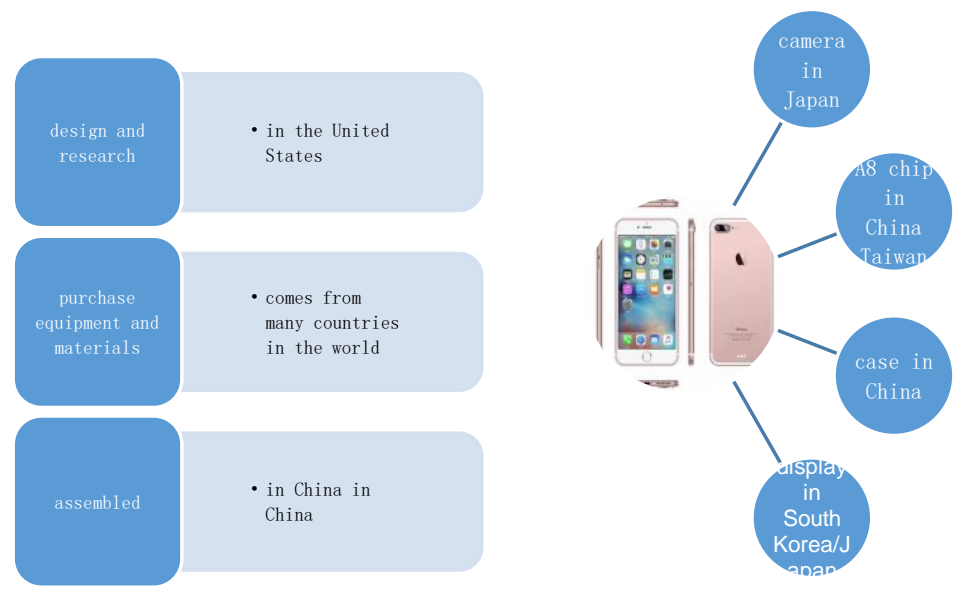

International companies have huge profits, but the global tax system's defects have led to tax avoidance and tax evasion. In the 2016 E.U. tax penalty case against Apple(Holtzblatt, Mark, A., Geekie, John, Tschakert, \& Norbert. (2016)), Apple had transferred intellectual property assets to the Irish operating company, and the cash paid by the user entered the account of the Irish sales company. After a series of international company operations, it was finally transferred to the Caribbean Islands' headquarters, a tax haven(Thierry Madiès, Tarola, O., \& Taugourdeau, E. 2021). This entire income circulation process only needs to pay low transaction tax and income tax, commonly known as the principle of tax avoidance in the "sandwich" structure. Therefore, Apple set up a sales company in Ireland, responsible for receiving all sales revenue except for the United States. It is nothing new for large multinational companies such as Google, Microsoft, Apple, and Amazon to transfer large amounts of intellectual property and cash to overseas tax havens through various channels. While international companies enjoy resources from all over the world and become more prosperous, they are also exploiting the loopholes in global governance flaws to gain the most significant benefit.

Economic globalization made people's food, clothing, housing, and transportation more diversified; cultural globalization has brought people progressive ideas; trade globalization has increased national 
income; organizational globalization has increased people's understanding of the world. However, the lower social groups cannot adapt to technology's globalization and cannot keep up with the times' updates (Zameer Hashim \& Vo Xuan Vinh 2020); when large machines and equipment moved into factories, workers are unemployed. Another important issue is income inequality (Eichengreen, B. J., Conto, B., ElganainA. A., \& Koczan, Z. . 2021). Low-income people are always suppressing at the bottom. Capitalcriticalinue squeezes people's surplus-value, and companies in some developing countries do not even consider employees' rest time. In the non-stop work, people lose the ability to think and will only serve capitalists' interests. Now that the globalization of immigration has led to an influx of more labor, workers' employment opportunities have decreased. Therefore, globalization is a double-edged sword, and how to adapt to it is a question that people should think about it.

\section{Discussion}

Anti-globalization is only a short historical process. The crisis caused by the current anti-globalization is mainly due to reducing the share of the developed countries in Europe and the United States in the international gains. Part of the new developing countries has the upper hand. To redistribute the world cake and firmly grasp their global advantages, European and American governments have directed and acted out anti-globalization, which is known for the benefit of the people. However, the United States has so many domestic contradictions that it has no time to control the international trend better, so it wants to retreat. Therefore, Trump proclaimed that the United States is the first to seek more welfare for the people and promote the return of industrialization. Global governance (Luís Brites Pereira, Maria Eugénia Mata \& Miguel Rocha de Sousa 2021) should break away from the control of the dominant country at an appropriate time, take back its sovereignty, and serve more small countries.

This globalization 5.0 American globalization is an enlarged version of the American system, so its rise and fall will follow the United States' pace. The rise in oil prices caused by the oil crisis in the 1970s was economic stagnation. The government implemented the decoupling of the U.S. dollar and gold, but it did not become a boost to the economy. The United States is sinking deeper and deeper in the quagmire of "stagflation". In 1974 and 1975, GDP experienced negative growth for two consecutive years after the Great Depression. The United States is once again in crisis. In 1977, Jimmy Carter, a peanut merchant and amateur carpenter Democrat from Southern Georgia, took office during the economic crisis. The first measure was to alleviate unemployment by increasing government investment and lowering federal taxes. The result is that the unemployment rate has dropped, but the inflation rate has soared.

When President Reagan took office in 1980, he used the "Reagan Economics" method of tax reduction, deregulation, and inflation to solve the sluggish economy. Huge military expenditures have stimulated the economy and science and technology. When he delivered his farewell speech in 1989, the U.S. economy had entered a period of prosperity. Both inflation and unemployment rates have dropped significantly from the beginning of the term. The information technology industry in the Reagan era suddenly emerged. Under the guidance of the new economy represented by computers and networks, the U.S. economy has realized another transformation, ushered in a new round of prosperity, and reached the peak of strength. 


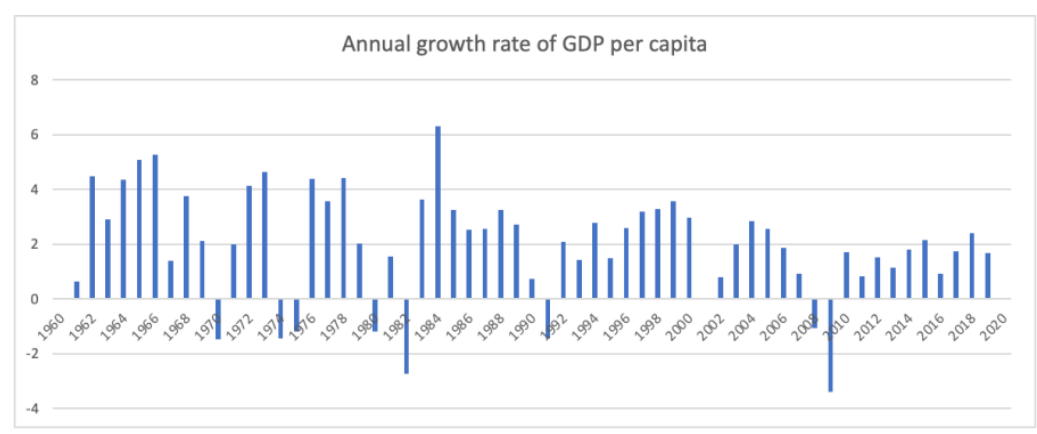

Sources: from world bank.com

Hundreds of billions of dollars wipe out, tens of millions of global laborers are unemployed, the U.S. Treasury has doubled, and the global poverty population has increased by 50 million. In 2008, many credit defaults originating from Wall Street in the United States made the global economy "buried" and triggered The global economic depression. Many debt defaults, mortgages that cannot pay, bank failures, financial market panics, capital flight, manufacturing bankruptcy, recession, and careers followed closely. Due to the global economic power of the United States, the recession of the United States has evolved into a worldwide problem. The beginning of this crisis was that the world's major economic forces and national forces began to shift, which determined the world economy and regime pattern ten years later. On the other hand, it also established the contradictory situation among the world's major economic powers today.

\section{The future of globalization}

There are several possibilities regarding the future of globalization: After the changes in the past few years, especially after the epidemic, people should understand the principle of "Our fate is one. Our future is one." Therefore, I hope that all countries and nations will unite from a rational perspective to respond to a series of challenges faced by humankind, including the epidemic, climate, and environment, to form the globalization of a world of great harmony indeed. I think the world structure will develop towards a regional system, such as RCEP. RCEP (Regional Comprehensive Economic Partnership Agreement) is currently the world's most populous free trade zone mechanism with the enormous development potential and the most diverse membership structure. It marks the common will of all countries in a region. The form of "blocking" began to appear decades ago, such as the European Union, ASEAN, the African Union, and South America. In the future, when global integration is struggling, and anti-globalization forces become stronger and stronger, "blocking" is most likely to appear. It is easier to solve problems within the regional relevance scope, and it is relatively easy to cooperate. I believe that globalization may develop into new globalization based on blocks. The most significant difference between this new block-based globalization and the US-led globalization is that there is no domination.

\section{References}

Eichengreen, B. J., Csonto, B., Elganainy, A. A., \& Koczan, Z. . (2021). Financial globalization and inequality: capital flows as a two-edged sword. IMF Working Papers.

Farmer Kevin C.(2021). Stress and strain on the U.S. drug supply: The intersection of shortages, globalization, counterfeit products, and throw in a global COVID-19 pandemic. 61(1), e85-e86.

Thierry Madiès, Tarola, O. , \& Taugourdeau, E. . (2021). Tax haven, pollution haven or both?. Working Papers. 
Ladi, S., \& Spyropoulou, V. . (2019). Greek Crisis. International Relations.

Thierry Madiès, Tarola, O. , \& Taugourdeau, E. . (2021). Tax haven, pollution haven or both?. Working Papers.

Luís Brites Pereira,Maria Eugénia Mata \& Miguel Rocha de Sousa(2021).Economic Globalization and Governance.Springer, Cham.

Obstfeld Maurice(2021). Two challenges from globalization. 110102301-.

Thierry Madiès, Tarola, O. , \& Taugourdeau, E. . (2021). Tax haven, pollution haven or both?. Working Papers.

Zameer Hashim \& Vo Xuan Vinh(2020). Reinforcing poverty alleviation efficiency through technological innovation, globalization, and financial development. 161

Zio Enrico(2021). Globalization and global risk: How risk analysis needs to be enhanced to confront current threats effectively. 205107270-.

Stephen D. King.Grave new world[M].Yale university press: America,2017:147. 